Jan 0. Aasly

jan.aasly@ntnu.no

Sigrid Botne Sando

Nevrologisk avdeling

Mona Undeland

Anders Waage

Medisinsk avdeling

St. Olavs hospital

7006 Trondheim

Pasientens pårørende har gitt samtykke til at artikkelen blir publisert

Oppgitte interessekonflikter: Ingen

Litteratur

1. Bassen FA, Kornzweig AL. Malformation of the erythrocytes in a case of atypical retinitis pigmentosa. Blood 1950; 5: $381-7$
2. Estes JW, Morley TJ, Levine IM et al. A new heredi tary acanthocytosis syndrome. Am J Med 1967; 42 868-81.

3. Danek A, Jung HH, Melone MA et al. Neuroacanthocytosis: new developments in a neglected group of dementing disorders. J Neurol Sci 2005 ; 229-30: $171-86$

4. Feinberg TE, Cianci CD, Morrow JS et al. Diagnostic tests for choreoacanthocytosis. Neurology 1991: 41: 1000-6.

5. Hardie RJ, Pullon HW, Harding AE et al. Neuroacan thocytosis. A clinical, haematological and pathological study of 19 cases. Brain 1991; 114: 13-49.

6. Rubio JP, Danek A, Stone $C$ et al. Chorea-acanthocytosis: genetic linkage to chromosome 9q21. Am J Hum Genet 1997; 61: 899-908.

7. Dobson-Stone C, Danek A, Rampoldi L et al. Mutational spectrum of the CHAC gene in patients with chorea-acanthocytosis. Eur J Hum Genet 2002; 10 : $773-81$
8. Ueno S, Maruki Y Nakamura M et al. The gene encoding a newly discovered protein, chorein, is mutated in chorea-acanthocytosis. Nat Genet 2001: 28: 121-2.

9. Aasly J. Skandsen T, Rø M. Neuroacanthocytosis the variability of presenting symptoms in two siblings. Acta Neurol Scand 1999; 100: 322-5

10. Okamoto $\mathrm{K}$, Ito J, Furusawa T et al. CT and MR findings of neuroacanthocytosis. J Comput Assist Tomogr 1997; 21: 221-2.

11. Margolese HC, Ferreri F. Management of conventional antipsychotic-induced tardive dyskinesia. J Psychiatry Neurosci 2007: 32: 72

Manuskriptet ble mottatt 8.6. 2006 og godkjent 5.6. 2008. Medisinsk redaktør Petter Gjersvik.

\title{
Kommentar
}

\section{Nevropsykiatrisk sykdom med hematologiske funn}

Sjeldne, alvorlige sykdommer kan lett bli oversett dersom symptomer og funn likner de kliniske manifestasjonene ved hyppig forekommende tilstander. Aasly og medarbeidere gir et godt eksempel på dette i sin omtale av en pasient med koreoakantocytose, en type nevroakantocytose.

I ramme 1 er det en oversikt over nevroakantocytosesyndromene $(1,2)$. Alle er svært sjeldne. De kjennetegnes av motoriske symptomer, men nevropsykiatriske symptomer og kognitiv reduksjon er også fremtredende. Ved koreoakantocytose inntrer disse symptomene ofte før de motoriske manifestasjonene (1), slik Aasly og medarbeidere beskriver. Det er derfor lett å forstå at koreoakantocytose kan forveksles med medikamentbivirkninger hos pasienter med kronisk psykiatrisk sykdom.

De siste ti årene er det gjort store fremskritt innen forståelse av etiologi og patoge-

\section{Ramme 1}

Nevrologiske syndromer med
akantocytose i blod $(1,2)$
Typisk nevroakantocytose
- Koreoakantocytose
- McLeods syndrom
Nevroakantocytose med lipidmalabsorpsjon
- Abetalipoproteinemi
- Hypobetalipoproteinemi
- Andersons sykdom
- Atypisk Wolmans sykdom
Tilstander med inkonstant akantocytose
Pantotenatkinaseassosiert nevro-
degenerasjon
- Chorea Huntington-liknende sykdom 2
Familiær akantocytose med paroksys-
mal anstrengelsesindusert dyskinesi
og epilepsi
- Mitokondriesykdom med akantocytose

nese ved nevroakantocytose $(2,3)$. Koreoakantocytose skyldes ulike, oftest recessivt arvelige mutasjoner i det såkalte CHACgenet (VPS13A-genet) på den lange armen av kromosom 9. Mutasjonene fører til manglende eller defekt produksjon av proteinet chorein og resulterer dermed i koreoakantocytose (2, 3). McLeods syndrom, som er kjønnsbundet arvelig, skyldes mutasjoner i XK-genet på X-kromosomet $(1,2$, 4). Det resulterer i defekt XK-protein. Dette er et membrantransportprotein med ukjent funksjon, og defekt fører til manglende ekspresjon av Kx-antigenet og svak ekspresjon av Kell-antigenet på erytrocyttoverflaten. Ekspresjon av erytrocyttantigener er lett tilgjengelig for blodtypeserologisk testing og utnyttes derfor diagnostisk.

Diagnosen nevroakantocytose bygger på kliniske symptomer og funn, hematologiske, serologiske, klinisk-kjemiske og molekylærgenetiske blodprøver og nevroradiologisk bildediagnostikk. Erytrocyttmorfologi står sentralt i diagnostikken, men som påpekt her og $\mathrm{i}$ annen litteratur (2) er rutinemikroskopi av blodutstryk ikke noen brukbar undersøkelse.

Påvisning av akantocytter krever noe øvelse i hematologisk morfologi, særlig fordi man må skille akantocytose fra ekinocytose, et uspesifikt, osmotisk femomen. Akantocytter kan forekomme ved andre tilstander enn nevroakantocytose og i et lite antall sannsynligvis hos friske individer (2). For å oppnå tilfredsstillende positiv prediktiv verdi er det derfor avgjørende at testen bare utføres ved klinisk begrunnet mistanke. Mikroskopi av May-GrünewaldGiemsa-farget blodutstryk fremstilt umiddelbart etter prøvetaking har vært benyttet (4), men gir sannsynligvis for lav sensitivitet. Elektronmikroskopi har vært angitt som gullstandard $(1,4)$, men er ikke lett tilgjengelig, og det er ikke vist at dette er bedre enn lysmikroskopiske metoder. Disse bør være standardiserte. Den metoden som er best evaluert i nyere litteratur, går ut på at fullblod fortynnes $1: 1$ med fysiologisk saltvann tilsatt heparin $(10 \mathrm{U} / \mathrm{ml})$, inkuberes i 30 minutter på vippe og undersøkes i tynt våtpreparat med fasekontrastmikroskopi (1, $2,5)$. Mer enn $6 \%$ akantocytter regnes som patologisk.

Diagnosen koreoakantocytose kan verifiseres ved choreinbestemmelse med Western blot-metodikk eller ved mutasjonsanalyse av CHAC-genet med PCR-basert metodikk $(1,3)$. Disse metodene er ikke tilgjengelige for rutinediagnostikk og bør først brukes når diagnosen er overveiende sannsynlig på klinisk og hematologisk-morfologisk grunnlag.

\section{Sigbjørn Berentsen}

sigbjorn.berentsen@haugnett.no

Medisinsk klinikk

Haugesund sjukehus

5504 Haugesund

\section{Oppgitte interessekonflikter: Ingen}

\section{Litteratur}

1. Walker RH, Jung HH, Dobson-Stone $\mathrm{C}$ et al. Neurologic phenotypes associated with acanthocytosis. Neurology 2007; 68: 92-8.

2. Danek A, Jung HH, Melone MA et al. Neuroacanthocytosis: new developments in a neglected group of dementing disorders. J Neurol Sci 2005 ; 229-30: 171-86.

3. Dobson-Stone C, Danek A, Rampoldi L et al. Mutational spectrum of the CHAC gene in patients with chorea-acanthocytosis. Eur J Hum Genet 2002; 10 773-81.

4. Hardie RJ, Pullon HWH, Harding AE et al. Neuroacanthocytosis: a clinical, haematological and pathological study of 19 cases. Brain 1991; 114 pathologic $13-49$.

5. Storch A, Kornhass M, Schwartz J. Testing for acanthocytosis - a prospective reader-blinded study in movement disorder patients. J Neurol 2005; 252: 84-90. 